\title{
Capital incorporador e ciclos imobiliários em Belém
}

Development capital and real estate cycles in Belém

Raul da Silva Ventura Neto [l]

\begin{abstract}
Resumo
Este artigo analisa a produção imobiliária realizada pelo capital incorporador em Belém, identificando as diferentes formas de organização das incorporadoras e construtoras durante o que identificamos como ciclos imobiliários. A metodologia conta com dados primários sobre a produção por incorporação em Belém, a forma de inserção de incorporadoras nacionais no circuito imobiliário local, com dados oficiais sobre o mercado de trabalho na construção civil, com base em informações da Rais, além de uma série de preços do metro quadrado dos imóveis nas últimas duas décadas, com base na pesquisa em classificados. Os resultados avançam na leitura histórico-estrutural sobre a formação e transformação dos circuitos imobiliários periféricos, visando desnudar como elites locais vêm direcionando a ação do incorporador no espaço intraurbano.
\end{abstract}

Palavras-chave: capital incorporador; circuito imobiliário; financeirização.

\begin{abstract}
The article analyzes real estate production organized by development capital in the city of Belém, identifying different organization forms of developers and builders during what we identify as real estate cycles. The methodology relies on primary data about production by development in Belém, the form of insertion of national developers in the local real estate circuit, official data about the civil construction labor market based on information from the Rais database, and a series of square meter prices in the last two decades, based on research into classified ads. The results contribute to the historical-structural reading about the formation and transformation of peripheral real estate circuits, aiming to reveal how the local elites have been directing the developers' action in the intra-urban space.
\end{abstract}

Keywords: development capital; real estate circuit; financialization. 


\section{Introdução}

No dia 23 de agosto de 2020, um conhecido jornalista de Belém anunciou em suas redes sociais que teriam desembarcado, na cidade, representantes da World Trade Center Association (WTCA) para prospectar o mercado local em busca de parceiros para o primeiro empreendimento com o selo da WTCA na cidade. Para a elite proprietária da cidade, que há décadas orquestra Belém como máquina imobiliária de crescimento, na qual verticalização e desenvolvimento imobiliário se tornaram símbolos controversos de desenvolvimento urbano (Ventura Neto, 2015), os ciclos imobiliários representam momentos cruciais de enriquecimento familiar e manutenção das estruturas de poder sobre a esfera local. Se somarmos a essa equação uma economia urbana em profunda crise: setor produtivo desestruturado e em franco movimento de desindustrialização, uma economia mais dependente dos salários provenientes da máquina pública, com a predominância de um terciário mal-remunerado e de alta rotatividade e metade da força de trabalho na informalidade (Ventura Neto et al., 2020), a atuação do capital incorporador local expõe como as elites proprietárias da cidade contornam as suas crises reservando o circuito imobiliário para os seus interesses de acumulação.

Neste artigo, partimos de uma abordagem histórico-estrutural sobre a produção imobiliária registrada em Belém, a partir da década de 1940, quando se iniciam os primeiros empreendimentos conduzidos pelo capital incorporador na cidade. Analisamos as diferentes formas de organização desse capital no circuito imobiliário na forma de ciclos imobiliários, atravessando a segunda metade do século XX até os dias de hoje, última fase de um ciclo iniciado no final dos anos de $1990 \mathrm{e}$ que foi marcado pela participação de incorporadoras de capital aberto.

Essas empresas avançaram para a periferia do sistema em virtude do modelo de real estate truncado que se desenvolve no Brasil, em que apenas a imersão da empresa no mercado de capitais se desenvolve, e não unidade habitacional, o que amplia a estrutura de capital dedicada à incorporação de novos terrenos, a base de capital da empresa e sua capacidade de endividamento (Shimbo, 2016). Em Belém, o crescimento explosivo no preço da terra urbana e dos imóveis, um dos elementos que caracterizou o último ciclo, veio acompanhado da abertura de uma nova fronteira imobiliária em parcelas da área de expansão metropolitana que possuíam estoque de terra com baixo valor de mercado (Ventura Neto e Lima, 2019).

Consideramos as mudanças no sistema de crédito que atende o circuito imobiliário um marco importante para definir momentos de mudanças de ciclo, pois tendem a representar rupturas substanciais no ambiente de investimentos que predominava no ciclo anterior. No caso de Belém, na passagem do primeiro para o segundo ciclo, entendemos que a ruptura ocorre com o início das operações do sistema de crédito para a construção de mercado do Banco Nacional de Habitação (BNH) e do Sistema Financeiro da Habitação (SFH), o que permite a desvinculação dos excedentes gerados na economia regional, que serviam de principal braço financeiro das incorporadoras e construtoras locais. Por conta disso, o ano 1966, quando o sistema BNH/SFH ganhou força pela constituição do Fundo de Garantia por Tempo de Serviço (FGTS) como seu principal funding (Royer, 2013), é considerado, neste 
trabalho, como o ano de início do segundo ciclo. A mudança do segundo para o terceiro ciclo está associada a rupturas ocorridas em período posterior à falência do BNH, em 1987, e que permitiram maior aproximação entre capital incorporador, mercado de capitais e sistema financeiro nacional. Por isso, associamos o fim do segundo ciclo, em Belém, e o início do terceiro à criação do Sistema Financeiro Imobiliário (SFI) em 1997. Este representa a primeira etapa de um novo ambiente institucional que serviu para a retomada dos lançamentos imobiliários na cidade, além da abertura de capital das grandes incorporadoras do Centro-Sul do País. As mudanças instituídas pelo SFI, apesar de não criarem nenhum tipo de funding novo e usarem os recursos mobilizados no SFH, apresentam novos instrumentos financeiros que, nos anos seguintes, serão fundamentais para pressionar o governo federal por mais instrumentos e alterações legais que ampliem a "segurança" dos agentes do mercado para retomar lançamentos imobiliários no País. ${ }^{1}$

A estrutura deste artigo divide-se em três partes, além das considerações finais. $\mathrm{Na}$ primeira parte, é apresentada uma revisão de literatura sobre o circuito imobiliário como espaço de controle e acumulação para elites locais e o papel do capital incorporador na mediação dessa dinâmica. Na sequência, a discussão passa a ser contextualizada com uma leitura histórico-estrutural da atuação do capital incorporador na configuração do espaço intraurbano de Belém, observado sobre o recorte dos dois primeiros ciclos imobiliários. $\mathrm{Na}$ terceira parte do artigo, são apresentados dados mais específicos sobre o último ciclo imobiliário, com destaque para a atuação das incorporadoras de capital aberto em associação com as incorporadoras locais, além de dados referentes à dinâmica do mercado de trabalho nos setores da construção civil e na dinâmica do mercado de terras nas áreas de maior atuação do capital incorporador durante o período. Ambos cobrem o período de 1999 a 2019 e foram coletados a partir das séries históricas de dados da Relação Anual de Informações Sociais - Rais/ME sobre vínculos e remuneração média dos empregados e a partir de levantamentos de campo no caderno dos classificados do jornal de maior circulação da cidade. ${ }^{2}$

Como principais resultados, apresentamos uma análise que se alinha à necessidade dos novos enfoques teóricos para a pesquisa em habitação, como sugere Maricato (2009), somando novas interpretações sobre o circuito imobiliário formado na periferia do capitalismo brasileiro que realçam o movimento dialético presente na tríade propriedade, canteiro e incorporação imobiliária. Defendemos, com isso, a necessidade de ampliação de pesquisas que avancem em abordagens histórico-estruturais sobre os circuitos imobiliários brasileiros, de modo a desnudar como o interesse de valorização do capital das elites locais vem direcionando a ação do incorporador no espaço intraurbano.

\section{Circuito imobiliário como órbita e os limites à centralização do capital incorporador}

O debate teórico a respeito da condição da terra como reserva de valor na economia brasileira foi encabeçado por autores como: Ignácio Rangel, Maria da Conceição Tavares, Carlos Lessa e Wilson Cano. Sem desagregar 
entre rural ou urbano, Tavares (1999) entende que a reserva de valor da terra seria condicionada por uma certa síndrome da liquidez, presente no padrão de investimento de algumas frações de capital nacional, incentivado pelo quadro permanente de instabilidade macroeconômica e inflação e que levaria a um quadro de busca constante por títulos de curto prazo e de alta rentabilidade.

De forma semelhante, mas contextualizando com a crise urbana brasileira, Rangel (2004) entende essa relação dentro de um quadro mais complexo. Para o autor, a função da terra como reserva de valor no subdesenvolvimento deveria considerar a Quarta Renda da Terra, um fenômeno que se estabelece em virtude do quadro de instabilidade da moeda e das expectativas do agente econômico sobre a liquidez do imóvel e da sua valorização no longo prazo. Essa condição leva à formação de uma demanda fundiária de cunho eminentemente especulativo, na qual o negócio imobiliário passa a corresponder a um negócio mobiliário. A partir disso, conectam-se, dado o elevado grau de concentração de propriedade que caracteriza o subdesenvolvimento brasileiro, formas de valorização do capital portador de juros a partir da valorização do ativo fundiário. Na visão de Rangel (ibid.), a taxa de juros do sistema, no longo prazo, tenderia a um padrão de rentabilidade inferior à rentabilidade com imóveis urbanos, impulsionando ainda mais a condição de reserva de valor do patrimônio imobiliário entre as classes dominantes e proprietárias.

Lessa (1980) e Lessa e Dain (1982) analisam as órbitas não industriais de acumulação e conectam a condição de reserva dos imóveis urbanos com o papel que o circuito imobiliário exerce na reprodução do capital das elites regionais. Primeiramente avançam em busca de uma conceituação do circuito imobiliário, como "frente de operações de transmutação e valorização de lucros dos capitais nacionais" (Lessa e Dain, 1982, p. 226). Seria, de fato, um circuito de valorização próprio do capitalismo associado brasileiro: produto da relação simbiótica entre capitais nacionais dominantes em órbitas não industriais e frações do capital internacional. Como órbita reservada às elites regionais, o controle do circuito imobiliário deve possibilitar, por meio da criação de frentes de valorização fictícia, sobretudo no urbano, níveis de rentabilidade nunca inferiores às órbitas industriais controladas pelo capital internacional, o que se torna possível mediante a emergência de um capital imobiliário que possui duas faces distintas. ${ }^{3} \mathrm{~A}$ face mercantil e dependente de benesses do Estado, que transparece no controle sobre estruturas de poder na esfera local ou em formas de articulação orgânico-constitutiva a fundos públicos reservados a programas habitacionais. E a face financeira, que promove a incorporação imobiliária como mera estratégia de emissão de ativo financeiro de longo prazo de retorno, que transforma a cidade em lócus de operações de lucros hipertrofiados do capital imobiliário (Lessa, 1980).

Alinhado ao pensamento de Lessa (ibid.), , Cano (2011) apresenta uma interpretação que busca articular a gênese do capital imobiliário, no Brasil, com o avanço da urbanização e da integração da economia nacional. O binômio urbanização/integração, ao pressionar pela modernização de estruturas produtivas regionais, estimula que titulares do capital mercantil regional fragmentem sua riqueza e se diversifiquem para novos setores, transvestidos de uma aparência moderna, mas mantendo lógicas arcaicas de valorização. 
Em espaços urbanos, o poder do grande proprietário fundiário enseja uma dinâmica local de acumulação primitiva que faz brotar o capital imobiliário como uma função especializada do capital mercantil nacional. Para Cano, como lembra Brandão et al. (2020, p. 10), o urbano aflora das estruturas de propriedade e, por conta disso, sua interpretação não pode prescindir do olhar sobre as relações contraditórias entre rural e urbano em cada contexto regional peculiar. Trata-se de relações que, por exemplo, envolveram a formação dos circuitos imobiliários das principais áreas urbanas no País, nas quais foram comuns os processos de convergência de excedentes produzidos em diferentes setores das economias regionais, na forma de investimento de elites locais em lançamentos imobiliários, normalmente coordenadas pelo capital de incorporação.

A intepretação sobre o capital de incorporação no urbano brasileiro tem como influência direta autores da crítica marxista dos anos 1970, como o economista inglês Michael Ball e o sociólogo francês Christian Topalov ${ }^{5}$ (Shimbo, 2020). Em linhas gerais, as referências sobre o tema estruturam-se em torno das ideias de Topalov (1979), que influencia diretamente o trabalho de Ribeiro $(1997)^{6}$ sobre o papel do incorporador na urbanização das cidades do Rio de Janeiro. 0 autor entende que o capital incorporador deve ser analisado como agente de suporte do capital de circulação necessário para a produção e negociação da moradia. Torna-se, dessa forma, o responsável pelas decisões de investimento e de coordenação do processo de produção, subordinando o construtor e assumindo o controle sobre as transformações do uso do solo para, de forma ativa, potencializar modos de apropriação sobre diferenciais de renda fundiária obtidas com a realização do empreendimento.

Além disso, é possível estabelecer paralelos entre as ideias presentes em Ball (1983) e o debate que se estrutura em torno de autores ligados mais diretamente à FAU-USP, como Ermínia Maricato, Paulo Cesar Xavier Pereira, Jorge Oseki e Ivonne Mautner (Shimbo, 2020). Ball (1983) joga luz na condição dos incorporadores como fração do capital industrial, já que o processo de acumulação que corresponde à produção da habitação, além da captura de renda fundiária, também é composto pela mais-valia obtida na exploração no canteiro. De forma semelhante, especialmente nos trabalhos de Pereira (1988; 2018), interpreta-se o incorporador e a firma de construção de uma forma organicamente articulada, assumindo que a reprodução do capital imobiliário resulta, de fato, de uma combinação entre a capitalização da renda da terra e a exploração do trabalho no canteiro.

$O$ suposto atraso estrutural no setor da construção - tema presente nos trabalhos de autores como Topalov - seria, na verdade, resultado da espiral permanente de elevação dos preços imobiliários em patamares sempre acima do preço de produção, já que a elevação da renda fundiária depende da elevação do preço no mercado, e não o inverso (Pereira, 2018). Essa condição, que o autor entende como estrutural na dinâmica de reprodução do capital no circuito imobiliário, abre a possibilidade permanente de "converter a construção num ramo com capacidade de absorção de trabalhadores e [...] um depósito do mercado de trabalho" (Pereira, 1988, p. 10), na medida em que, para o incorporador e construtor, 
o desestímulo à elevação da produtividade do trabalho no canteiro "resulta da propensão para se dedicar aos meios de manipulação da renda e do mercado" (Pereira, 2018 p. 77).

Para Rufino (2012), o surgimento do capital de incorporação não representa a ruptura completa de condições de acumulação pretérita daquela economia urbana, mas sim uma forma de facilitação da inserção do excedente de outras frações do capital no circuito imobiliário. Uma vez estruturada, a cada ciclo de reprodução, a concorrência capitalista induz a processos de concentração entre as frações do capital que atuam no imobiliário, em particular nas empresas de incorporação e construção.

O sistema de crédito que foi estruturado no Brasil para servir à incorporação imobiliária, especialmente o SFH, permitiu superar limites de investimentos associados à poupança disponível nas economias locais (Ribeiro, 1997). Mas não foi suficiente para modificar dinâmicas diferenciadas de reprodução do capital incorporador no circuito imobiliário, que envolvem: a fixação da mercadoria no solo, a fraca homogeneidade no território urbano e as frágeis barreiras de entrada no setor. Essas três razões seriam responsáveis por obstruir "a centralização do capital na forma como ocorre em outros ramos da indústria de transformação" (Sanfelici, 2016 p. 15). Os limites de reprodução do capital incorporador ampliam as possibilidades de preservação do circuito imobiliário como órbita reservada para elites locais, para as quais prevalecem lógicas mercantis de valorização como destacou Cano (2011)

Em linhas gerais, os circuitos imobiliários mantiveram a condição de órbita reservada até os anos 2000, mesmo representando um espaço importante para captura de renda fundiária urbana, cada vez mais necessária para o mundo contemporâneo das finanças (Rolnik, 2015). A partir de 2005, tem início um movimento de aproximação entre grandes incorporadoras e o mercado de capitais, principalmente daquelas que atuavam nos circuitos imobiliários de São Paulo e Rio de Janeiro e vivenciavam um ambiente favorável para investimentos em habitação de mercado, por conta de condições macroeconômicas favoráveis que se combinavam a novas formas de acessar fundos públicos, particularmente o FGTS (Royer, 2016). 0 contexto de expectativas positivas para novos investimentos foi decisivo para a decisão de abrir capital na bolsa de valores de São Paulo, o que veio a tornar um marco temporal do avanço da financeirização sobre o circuito imobiliário nacional, por conta um novo patamar de concentração estabelecido em torno dessas empresas, além de um inédito processo de centralização que envolveu diversas formas de fusões, aquisições e associação entre incorporadoras e construtoras de todo o País (Lencioni, 2014; Sanfelici, 2016; Fix, 2011).

De fato, a entrada dessas empresas no mercado de capitais configurou o que Shimbo (2010) nomeou de real estate à brasileira, na medida em que foram as frações da empresa que se converterem nos ativos transacionados no mercado financeiro e não a unidade habitacional, diferindo do modelo estadunidense que serviu, ao menos no discurso, de espelho para o modelo brasileiro. Com isso, o valor da empresa nos pregões da bolsa tomou como referência parâmetros de desempenho presentes que já eram utilizados pelo mercado, fazendo com que a corrida pela ampliação no banco de terrenos e projeção dos Valores Gerais de Venda (VGV) passassem a servir de base para a criação de capital fictício (Fix, 2011), ao mesmo tempo que estimulou processos de 
racionalização do projeto de arquitetura dos empreendimentos e novas formas de gestão do canteiro (Shimbo, 2010; Baravelli, 2017; Anitelli e Tramontano, 2016).

As antigas famílias proprietárias das grandes incorporadoras mantiveram-se próximas das principais esferas de decisão, ao menos naquele momento inicial. Com isso, o capital financeiro, representado pelos acionistas, não precisou assumir as rédeas do canteiro de obras ou das estratégias de expansão territorial, contanto que o VGV previsto nos relatórios financeiros fosse efetivamente obtido (Fix, 2011). Mesmo assim, os financistas passaram a orientar parâmetros gerais de atuação dos agentes do circuito imobiliário, o que permitiu a elevação do grau de exploração do canteiro, além da explosão do valor da terra urbana nas cidades em que esses grupos passaram a atuar. O movimento especulativo em torno da aquisição de novos terrenos obrigou incorporadoras a extrapolarem seus limites tradicionais de atuação aterrissando no circuito imobiliário de Belém, que se encontrava em pleno ciclo expansivo (Ventura Neto, 2015).

$\mathrm{Na}$ verdade, o circuito imobiliário de Belém já operava, há mais de cinco décadas, como espaço reservado de acumulação para elites regionais e de redirecionamento de excedentes de outros setores da economia regional. A entrada das incorporadoras nacionais de capital aberto, ao promover um movimento de centralização do capital, tencionou a condição de hegemonia das incorporadoras e construtoras locais, acelerando processos de reestruturação espacial na área de expansão da cidade. Com a saída das incorporadoras nacionais, o preço da terra urbana em Belém acelera possibilidades de investimento em novos empreendimentos, o que tem levado a uma nova rodada de lançamentos imobiliários entre incorporadoras e construtoras locais, tanto as que atravessaram o período e mantêm-se ativas, quanto os novos incorporadores locais que surgem impulsionados pelos mesmos motivos.

\section{Ciclos imobiliários e a ação do capital incorporador na estruturação do intraurbano de Belém (1940-1997)}

Os primeiros registros de incorporação imobiliária em Belém datam do final dos anos 1940, impulsionados pelo reinvestimento de excedentes de grupos exportadores, especialmente castanha-do-Pará, proprietários do pequeno parque industrial local e empresas importadoras de manufaturas e bens que não eram produzidos na Amazônia àquela altura. O movimento de reestruturação endógena da economia Amazônia, após o ciclo de exportação gomífera, foi fundamental para que as dinâmicas de reinvestimentos dos excedentes no circuito imobiliário de Belém permitissem estruturá-lo como circuito autônomo de valorização do capital mercantil regional, reforçando a sua condição de principal reserva de valor da economia regional (Ventura Neto, 2017).

Esse período marca o que neste artigo elencamos como primeiro ciclo imobiliário. Um período, de aproximadamente 16 anos, que tem como referência para a periodização a entrega do primeiro edifício realizado por meio de incorporação imobiliária, em 1940. Durante o primeiro ciclo, as transformações no espaço construído de Belém praticamente se restringem à principal avenida da área central da cidade, contando com o apoio direto 
da prefeitura que participou como doadora de terrenos de sua propriedade ao longo da avenida, sob o discurso de que a verticalização significava a modernização e o progresso da cidade (Chaves, 2011).

Além disso, mesmo com a facilidade da doação dos terrenos, a inexistência de um mercado financeiro local ou de um sistema de crédito capaz de viabilizar empréstimos de longo prazo inviabilizava o surgimento do capital incorporador de forma autônoma e desvinculada dos excedentes produzidos em outros setores da economia regional. A busca por entesourar os excedentes na forma de imóveis urbanos faz com que as frações do capital mercantil regional passassem a agregar em torno de si tanto o caráter comercial quanto o caráter financeiro do capital imobiliário, criando no interior da unidade empresarial dois circuitos de valorização do capital distintos, mas organicamente articulados, acompanhando os moldes definidos por Lessa (1980). A partir daí investimento em imóveis urbanos representava uma forma de conexão direta entre o faturamento do grupo empresarial e a criação de capital fictício. A valorização imobiliária obtida com as vendas das unidades e, até mesmo, com a especulação com a propriedade urbana passou a ser incorporada como lucro nos balanços anuais das empresas de Sociedade Anônima de Capital Fechado, estrutura empresarial que predominava na economia paraense naqueles anos (Ventura Neto, 2017).

Os balanços das empresas de exportação, importação e indústrias são uma das principais fontes de dados quanto a forma e magnitude de autonomização do circuito imobiliário de Belém, ainda na década de 1950. Mesmo sem um marco regulatório para reger a incorporação de edifícios, além da inexistência de mercado de qualquer tipo de capitais endógeno à região, o que inviabilizava formas de centralização, o capital incorporador estabeleceu-se das mais diversas formas, centralizando as etapas de incorporação, construção e venda das unidades habitacionais. 0 exemplo mais caricato diz respeito à empresa Cinemas e Teatros Palácio que, apesar de possuir os principais cinemas da cidade, atuava também como incorporadora imobiliária, tendo como sócio e tesoureiro o empresário Wady Chamiê, proprietário da maior firma de beneficiamento e exportação de castanha-do-Pará da região Norte. Em linhas gerais, o capital incorporador local logrou estruturar o circuito imobiliário de Belém por meio de três caminhos distintos: 1 ) o reinvestimento de lucros do grupo empresarial, com o patrimônio imobiliário passando a compor os ativos imobilizados da empresa; 2) a formação de empresas de sociedade aberta de capital fechado empresas S.A. - constituídas unicamente para viabilizar a incorporação e construção do empreendimento imobiliário; 3) a participação do empresário local como braço financeiro de uma incorporadora não diretamente vinculada à sua empresa (ibid.).

O caso da empresa Importadora de Ferragens S.A. ${ }^{7}$ é bastante ilustrativo para observar a autonomização do circuito imobiliário em Belém naquele período. Em pouco mais de 15 anos de análise dos balanços, a participação de imóveis havia saído de 5,2\%, em 1945, para $11,05 \%$ do ativo total da empresa em 1960, saltando de $\mathrm{Cr} \$ 65$ milhões para $\mathrm{Cr} \$ 90 \mathrm{mi}$ Ihões, dentro de um ativo total que correspondia ao montante de Cr812 milhões. ${ }^{8}$ Um crescimento que estava atrelado ao fato de a Importadora de Ferragens ter se constituído como incorporadora de imóveis, lançando um dos primeiros edifícios da região central de Belém, 
que simbolizava o avanço de formas de modernização da arquitetura e planejamento urbano da cidade (Chaves, 2011). A construção do Edifício Importadora teria consumido cerca de 30 milhões de cruzeiros, entre os anos de 1949 e 1954, e teve os lucros obtidos com a venda e aluguel de imóveis incorporados ao balanço da empresa. Com a construção do edifício, o ativo total da Importadora de Ferragens apresentou, entre 1955 e 1960, uma taxa média anual de crescimento de $12,78 \%$ a.a., e, se compararmos com o balanço anterior à incorporação do edifício, entre os anos de 1950 e 1960, essa taxa se eleva a patamares de $68,94 \%$ a.a.

$\mathrm{O}$ binômio $\mathrm{BNH} / \mathrm{SFH}$ consolida o incorporador como o vértice dos mercados de terras, de construção e de crédito no Brasil (Ribeiro, 1997, p. 301). Trata-se de uma realidade que possivelmente ocorreu em ritmos distintos, incorporando as especificidades da urbanização de cada região do País. No caso de Belém, o acesso aos recursos mobilizados pelo BNH permitiu a fragmentação do capital incorporador e a especialização do circuito imobiliário local em nichos com estruturas de concorrência distintas entre si, que, da mesma forma, abrigavam incorporadoras e construtoras também distintas em escalas e frentes de atuação. Essa fragmentação é motivada pelo público-alvo e as linhas de financiamento que se adequavam aos empreendimentos, com o segmento mais popular ficando a cargo da Companhia de Habitação do Estado do Pará (Cohab-PA), criada em 1967.

A fragmentação do capital incorporador local resultará em, ao menos, três padrões distintos de estruturação do espaço intraurbano de Belém. Sem desconsiderar que a ocupação intraurbana da Região Metropolitana de Belém (RMB) tenha sido fortemente determinada por estratégias de ocupação espontâneas em diferentes tipologias, como mostram Pinheiro et al. (2016), a infraestrutura produzida pelo incorporador local, sobretudo a Cohab-PA, serviu de suporte indireto para as ocupações informais que ocorreram na área de expansão metropolitana durante os anos de 1980 e 1990, determinando o padrão disperso de espraiamento sobre o território metropolitano que caracterizou a metrópole até os anos 2010 (Trindade Jr., 2019).

0 padrão de ocupação conduzido pela Cohab-PA foi pautado pela produção de conjuntos habitacionais esparsos e de baixa densidade, respondendo às diretrizes de planejamento definidas para a RMB onde intencionava a consolidação de subcentros nos municípios da área de expansão metropolitana (Santos, 2011). Os conjuntos "Cidades Novas" em Ananindeua, com mais de 9 mil unidades habitacionais, mas também outros conjuntos de menor porte construídos em Belém, na região da rodovia Augusto Montenegro, serviam claramente a esse propósito. Em outra frente de atuação, o capital incorporador local atendia à linha de financiamento do BNH dedicada às cooperativas habitacionais (Coophab) a partir de incorporadores de pequeno porte ou de grandes incorporadoras que se transvertiam de cooperativas habitacionais (Trindade Jr., 1998). Esses incorporadores atuaram de forma articulada às áreas que a Cohab-PA "desbravava", ou seja, onde esta havia sido a primeira empresa a construir algum tipo de infraestrutura urbana, com destaque para a região da rodovia Augusto Montenegro, que duas décadas depois se tornou uma importante frente de investimento das grandes incorporadoras de capital aberto que atuaram durante o terceiro ciclo (Ventura Neto, 2015). 
Com atuação direcionada para classes médias e elites locais, estavam os incorporadores que se conectavam ao $\mathrm{BNH} / \mathrm{SFH}$ por meio do Sistema Brasileiro de Poupança em Empréstimo (SBPE), atendendo famílias com renda superior a 6 salários-mínimos (SM) ou então os poucos grupos locais, do segmento médio e médio alto, que não dependiam do $\mathrm{BNH}$. A torre residencial de múltiplos pavimentos, localizada nas regiões de melhor acessibilidade e infraestrutura urbana, além das avenidas de cotas mais altas ou algumas baixadas saneadas (Ponte, 2010), tornou-se a tipologia predominante dos empreendimentos conduzidos por essa fração do capital incorporador local. Nesse primeiro momento, as torres residenciais beneficiavam-se de permissividades nas diretrizes de Ordenamento Territorial de Belém que determinavam restrições irrisórias ao aproveitamento do terreno e à taxa de ocupação do lote (Ventura Neto e Moura, 2019).

Ao longo dos anos de 1980, a produção de habitação de mercado em Belém acelera, atingindo um pico de entregas de empreendimentos no ano de 1987, mesmo ano em que é instituída a falência do BNH e tem início um período marcado por instabilidades na política habitacional do governo federal, além de graves restrições nas linhas financiamento para as atividades imobiliárias de mercado (Royer, 2013). Foi durante essa década, no entanto, que Belém passa a ser palco de um acelerado processo de urbanização que a coloca na amarga condição de cidade com mais de $1 \mathrm{mi}-$ Ihão de habitantes, elevando o déficit habitacional e pressionando ainda mais o poder local por políticas habitacionais eficazes.

Diferentemente do primeiro ciclo, que teve como produto apenas uma frente imobiliária bastante restrita, durante o segundo ciclo, serão consolidadas duas potenciais frentes imobiliárias distintas, fundamentais para ampliar os lucros do capital incorporador local no próximo ciclo de investimentos. A primeira frente tem lugar em regiões de baixadas saneadas da área central da cidade, onde havia uma importante reserva de terrenos bem localizados e integrados às principais artérias da cidade, formados por vacarias ${ }^{9} \mathrm{e}$ galpões das indústrias do antigo parque industrial da cidade, que se encontravam em plena decadência nos anos de 1980 (Trindade Jr., 1997).

A segunda frente, por sua vez, estabeleceu-se em parcelas específicas da região da rodovia Augusto Montenegro, de pior integração à área central de Belém, mas com grandes glebas de uso rural desdobradas da fazenda Val-de-Cães no início do século XX e de baixo valor de mercado. Por conta disso, encontravam-se aptas para receber condomínios residenciais voltados para um público de alto padrão de renda, uma tendência que se consolidaria, na região, a partir dos anos 2000 e que teve como pioneiro o condomínio Greenville, lançado ainda em 1988 pela construtora e incorporadora Villa Del Rey, incorporadora local que, até então, tinha atuado somente no segmento médio do BNH. Esse ponto é central, pois, apesar da condição de periferia distante da área central, a valorização do Greenville fez com que incorporadores e grandes proprietários de terra observassem o potencial de atração da classe média alta e mesmo de parcelas da elite de Belém para a região da Augusto Montenegro. A especulação com os terrenos da área levou à subutilização ou mesmo a não utilização dos lotes de melhor acessibilidade, especialmente os lindeiros aos principais eixos de mobilidade. 
O sistema de crédito organizado pelo $\mathrm{BNH}$ era determinante para o funcionamento do circuito imobiliário de Belém, e a falência do banco, somada a outros fatores estruturais, contribuiu para o encerramento de diversas incorporadoras e construtoras que atuaram durante o segundo ciclo imobiliário em Belém (Figura 2). Observando dados de financiamento para o Pará, ${ }^{10}$ compilados até 1985 , observa-se que, durante o tempo de funcionamento do banco, cerca de 23 mil unidades (32,21\% do total) foram financiadas via recursos do SBPE, aproximadamente 19 mil unidades $(26,17 \%$ do total) foram construídas pela Cohab-PA e pouco mais de 5 mil unidades (7,67\% do total) foram construídas por cooperativas habitacionais (Idesp, 1990).

O elevado grau de dependência das incorporadoras que sobre os recursos do SBPE fez com que boa parte da década de 1990 fosse marcada por uma produção imobiliária de mercado limitada às camadas de alta renda, via produção por administração ou autofinanciada. 0 ritmo de novos lançamos e o prazo das entregas dos empreendimentos dilataram, em que pese o reduzido público capaz de arcar com os custos da produção autofinanciada. Esse contexto impactou diretamente na redução das atividades imobiliárias nos espaços de maior atividade imobiliária do segundo ciclo e nos rumos futuros da atuação do capital incorporador local.

A Cohab-PA manteve-se em funcionamento, por meio de uma participação maior de aportes para custeio vindos de recursos do governo estadual, resumindo sua atuação na produção de lotes urbanizados, no subsídio para a compra de material de construção para famílias com baixo padrão de renda e na produção restrita de empreendimentos habitacionais de pequeno porte, direcionados a funcionários públicos do estado, além de assumir o posto de órgão estadual responsável pelo planejamento urbano da RMB. As incorporadoras que atuavam no segmento econômico do BNH tiveram destinos diversos, podendo ser identificadas ao menos duas tendências. Uma parcela migrou para o segmento de média e alta renda, passando a operar com construção autofinanciada ou por administração; enquanto outra parte das empresas manteve atuação na produção de moradia popular, captando recursos por meio de programas que previam a parceria entre setor empresarial e governo federal, como: o Plano de Ação Imediata para Habitação (Paih), o Plano Empresário Popular (PEP) e o Programa de Habitação Popular/Setor Privado (Prohap/SP) (Trindade Jr., 1998).

Os dados compilados no Gráfico $1^{11}$ apresentam o total de entregas de empreendimentos imobiliários, realizadas por meio de incorporação, por ano na cidade de Belém, incluindo dados para os três ciclos imobiliários que estão sendo analisados neste artigo. É possível observar que o pico de entregas do segundo ciclo ocorreu em meados dos anos de 1987, representando empreendimentos que foram lançados de quatro a cinco anos antes, ou seja, foram lançados entre os anos de 1982 ou 1983, que coincidem como o período de menor entrega de empreendimentos da série. A primeira metade dos anos 1990 ainda é marcada por empreendimentos lançados nos últimos anos de existência do BNH, enquanto, na segunda metade da década possivelmente, predominam empreendimentos realizados por administração ou autofinanciados. 0 pico de entregas do terceiro ciclo ocorre no ano de 2008 (Gráfico 1) e mantém um ritmo superior a 20 entregas por ano até 2016, quando a crise no setor se aprofunda. 
Gráfico 1 - Emissão de Habite-se por ano, para edifícios produzidos por incorporadoras e/ou construtoras

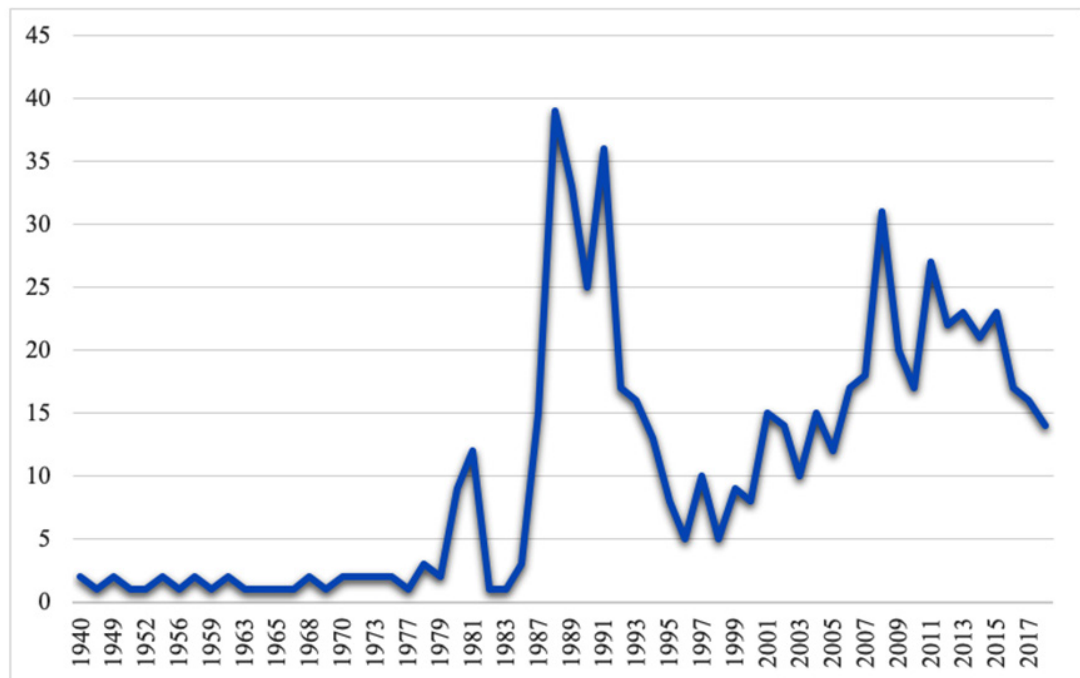

Fonte: Seurb; Núcleo Belém do Observatório das Metrópoles. Elaboração: Raul Ventura Neto.

\section{Terceiro ciclo imobiliário: a dialética entre incorporação, canteiro e propriedade fundiária}

A retomada de entregas de novos empreendimentos ocorre a partir do início dos anos 2000, convergindo com a entrada em vigor da Lei Complementar de Controle Urbanístico de 1999 (LCCU/1999) que, após seis anos de análise na câmara municipal de Belém, teve seu texto substancialmente alterado pelos vereadores em trechos que tratavam do coeficientes de aproveitamento e do pagamento de outorga onerosa nas zonas em que se localizavam regiões de baixada saneada da área central da cidade, frente imobiliária em potencial, constituída durante o segundo ciclo (Ventura Neto, 2015). A melhoria das condições macroeconômicas a partir dos anos 2000 permite a retomada dos lançamentos imobiliários em ritmo crescente entre incorporadoras e construtoras locais. Isso se observa principalmente nas entregas entre 2001 e 2007 e segue constante mesmo com a entrada das incorporadoras de capital no circuito imobiliário de Belém, o que ocorre a partir de 2007. No mesmo período, o Pará era o estado com maior volume de captação de recursos do SFH da região Norte, com valores superiores à maioria dos estados do Nordeste (ibid.), o que reflete na atuação das incorporadoras e construtoras locais, que, no período, entregaram 101 torres de 
apartamentos, sobretudo na área central de Belém e em regiões de baixada saneada, que possuíam elevado coeficiente de aproveitamento nos terrenos, depois das "facilidades" obtidas com a LCCU/1999. ${ }^{12}$

Os modelos urbanísticos para edifícios multifamiliares da LCCU/1999 foram "reaproveitados", em 2008, no zoneamento proposto para o Plano Diretor do Municípios de Belém, e mantêm-se ativos até hoje, ${ }^{13}$ tornando-se o quadro de modelos urbanísticos com o maior tempo de duração na história de Belém. No zoneamento proposto para o plano diretor de 2008, as zonas que, na LCCU/1999, possuíam os maiores coeficientes de aproveitamento foram unificadas em torno da Zona de Ambiente Urbano-6, que representa a área que concentra mais de $80 \%$ da verticalização de Belém (Figura 1).

As permissividades do quadro de modelos e dos parâmetros urbanísticos da LCCU/1999 incentivaram a ocupação de miolos de quadras por torres de apartamentos, gerando a supressão de área vegetada presente nesses espaços e sua impermeabilização pela construção da área condominial dos empreendimentos (Ventura Neto e Moura, 2019). Em agravo, alguns edifícios de alto padrão entregues ou lançados, no período, contribuíram para consolidar uma dinâmica de apropriação imobiliária da paisagem da orla da cidade como elemento diferencial das unidades imobiliárias (Ponte, 2010), incorporando a exclusividade da paisagem da orla - renda de monopólio - no preço final da unidade. Dados desse tipo são fundamentais para compreender como a atividade imobiliária de mercado, mediada por instituições frágeis de controle urbanístico, como é o caso de Belém, segue acentuando trajetórias de transformação do ambiente construído que pressionam as condições de sustentabilidade urbana da cidade, como identificado em Cardoso e Ventura Neto (2013).

A entrada das incorporadoras de capital aberto no circuito imobiliário de Belém é resultado do movimento de centralização do capital incorporador que ocorre no circuito imobiliário nacional a partir de 2007 (Lencioni, 2014; Sanfelici, 2016) que, no caso de Belém, deu-se sob diversas formas de associação com as principais incorporadoras e construtoras do circuito imobiliário local. 0 know-how - expressão financeirizada para o velho "conhece o mercado" - aparecia aos investidores como principal função dessa parceria, anunciada como estratégica pelo incorporador nacional para superar diferenças regionais. Como bem destacou o diretor regional de uma incorporadora nacional em entrevista, é "o sócio local que abre muito essa questão do futuro, o que é que tem em projeto hoje se pensando pra região" (grifo nosso). Nos relatórios anuais da Gafisa, ${ }^{14}$ por exemplo, é explícita a função das parcerias locais como uma forma de "novos mercados de forma eficiente", o que, de fato, traduzia em facilidades para captar terrenos, privilegiando a permuta, ${ }^{15}$ da qual o parceiro era facilitador da indicação e negociação da terra urbana.

Se olharmos de forma agregada, durante o período de atuação desses grupos, que inicia em 2007 e finaliza em 2015, quando já não ocorrem mais novos lançamentos imobiliários por parte dessas empresas, as incorporadoras de capital aberto que aturam em Belém apresentaram, para o período, um VGV projetado superior a 2 bilhões de reais a preços de hoje. Um montante de capital fictício que se encontrava cristalizado em empreendimentos das mais diversas tipologias, públicos e padrões de investimento. A venda relâmpago das 
primeiras etapas do Alphaville Belém, em pouco mais de quatro horas, com quatro milhões de metros quadrados e distando 11 quilômetros do centro de Belém, ou então o caso das primeiras torres residenciais de alto padrão lançadas em regiões da cidade, até então, tidas como periferias metropolitanas, são apenas alguns casos que evidenciavam a capacidade de transformação do grande incorporador de capital aberto sobre o espaço intraurbano da metrópole.

Em uma tentativa de síntese dessa atuação, defendemos que a dimensão espacial dessa fração do capital incorporador sobre o intraurbano trouxe como variável dependente para a sua inserção e reprodução, por meio de ampliação da renda fundiária que poderia ser capitalizada a partir do circuito imobiliário de Belém. Para tal, era fundamental a possibilidade de imposição conjunta de dois movimentos distintos: 1) a síntese de novos consensos espaciais para a população urbana, impondo uma dinâmica de ressignificação simbólica e material de regiões pouco valorizadas pelas camadas médias e elites locais; 2) a dissolução de barreiras espaciais que estavam fora dos limites de investimento do capital incorporador local, tais como: grandes glebas urbanas vagas ou subutilizadas ou, até mesmo, estruturas robustas fixadas no ambiente construídas em momentos anteriores da história da cidade.

O primeiro movimento é notadamente simbolizado pela aquisição e derrubada do Moinho Cruzeiro do Sul, localizado em região de baixada saneada, cujo potencial de valorização estava presente no fim do segundo ciclo. 0 moinho foi adquirido pela Cyrela Brazil Realty, em 2011, para dar lugar a três torres, duas residenciais e uma comercial, de altíssimo padrão construtivo, elevando os empreendimentos dessa área, que possui vista privilegiada para a orla da cidade, a um novo patamar de preços, como mostro no tópico a seguir. $\mathrm{O}$ segundo movimento, mais extensivo no território e articulado com outras incorporadoras nacionais foi simbolizado por construção simbólica em torno da região da avenida Augusto Montenegro, ${ }^{16}$ servindo-se das glebas de melhor acessibilidade da região, cujo potencial de valorização também se estabeleceu no fim segundo ciclo, sendo mantidas praticamente subutilizadas desde então. Dentro dessas dinâmicas, o que um dia foi visto como região reservada para o segmento econômico do $\mathrm{BNH}$, do dia para a noite converteu-se no local em que "a Nova Belém está sendo construída", slogan publicitário largamente utilizado, a partir de 2010, nos empreendimentos lançados na região, inicialmente pelas incorporadoras de capital aberto e, posteriormente, por incorporadoras locais.

A construção do conceito "Nova Belém" era parte da estratégia de atuação das incorporadoras de capital aberto para atingir o VGV previsto para os empreendimentos, pois atribuía aos novos imóveis lançados na região uma condição de monopólio. Especular com o monopólio de localizações é fundamental para a reprodução do capital de incorporação e obriga a construção de estratégias para acelerar dinâmicas de reestruturação intraurbana, como a que vem ocorrendo em Belém desde os anos de 2010. Em complemento, a reestruturação que produziu a nova Belém só foi possível graças a um processo de reorganização brutal do canteiro de obras dessas empresas, como forma de ampliar o controle sobre a jornada de trabalho do operário (Shimbo, 2010; Baraveli, 2017). 
Figura 1 - Empreendimentos (pontos azuis) produzidos por incorporação de acordo com os ciclos

Em linha vermelha, o limite da ZAU-6
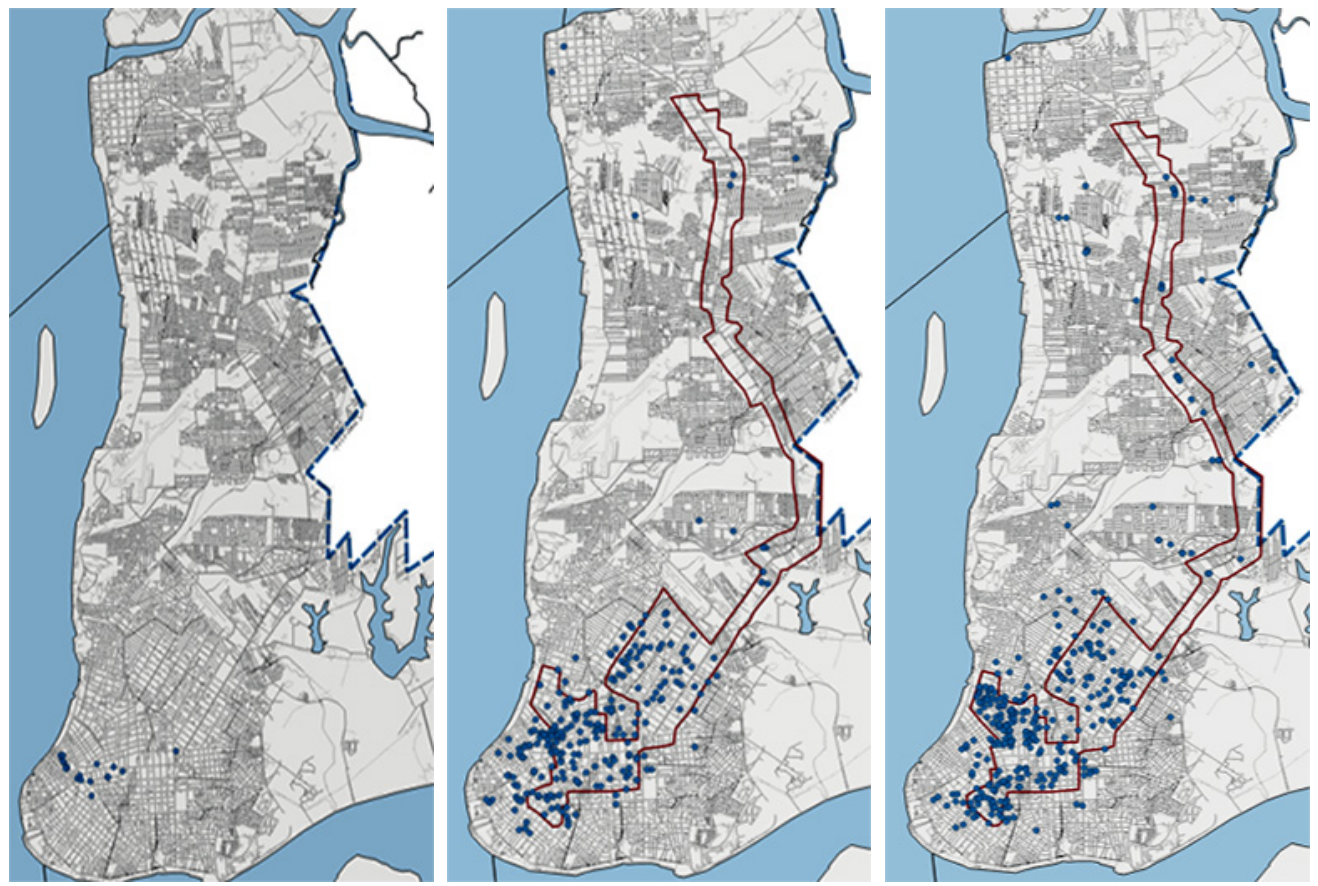

Fonte: IBGE, 2020; Seurb; Núcleo Belém do Observatório das Metrópoles. Elaboração: Raul Ventura Neto.

O avanço da centralização entre empresas do circuito imobiliário local e, até mesmo, a adoção de novos ferramentais analíticos para orientar decisões de projeto entre incorporadoras e construtoras locais (Santana, Lima e Ventura Neto, 2021), a condição do canteiro como "depósito de trabalhadores" (Pereira, 1998 e 2018) parece ter se mantido durante 0 terceiro ciclo.

As análises apresentadas a seguir representam uma tentativa de posicionar, ainda que de forma restrita, dada a escassez de observações em campo, evidências de que o aumento da intensidade da jornada de trabalho entre os trabalhadores do canteiro de obras em empresas de construção de edifícios deve ser considerado como parte componente da reprodução do capital incorporador local no circuito imobiliário.

Os dados mais gerais sobre a dinâmica do mercado de trabalho na RMB, para o período de 2006 a 2016, revelam a baixa participação da construção civil e do imobiliário na economia metropolitana, na qual a maior parte dos vínculos e da massa salarial se concentram em ramos da administração pública, respectivamente $30 \%$ dos vínculos e $48,8 \%$ da massa salarial. Considerando todos os ramos da construção civil, ${ }^{17}$ no melhor ano da série de dados (2014), o setor empregou menos $8 \%$ dos 
vínculos totais registrados para o período. Esse montante correspondia a aproximadamente metade dos empregos da administração pública, mas representava uma massa salarial inferior a $5,0 \%$ do total para a $\mathrm{RMB}$, com o ramo de construção de edifícios representando um pouco mais da metade desse valor, enquanto a administração pública respondia a quase metade da massa salarial gerada na economia metropolitana (Ventura Neto et al., 2020).

Se desagregarmos em faixas salariais os vínculos registrados na Rais, ${ }^{18}$ apenas para as empresas de construção de edifícios localizadas em Belém, para o período de 1999 a
$2019,{ }^{19}$ observaremos como os possíveis efeitos diretos de renda a partir de investimentos na construção civil parecem impactar, sobretudo, nas faixas acima de $10 \mathrm{SM} .{ }^{20}$ Os dados do Gráfico 2 mostram que, durante o terceiro ciclo, foi registrado um crescimento expressivo do número de vínculos entre os trabalhadores diretamente ligados ao canteiro de obras, os situados nas faixas de 1 a 2 SM em média, entre 2009 e 2013, período de maior crescimento do ciclo. Nessa faixa, os vínculos saíram de quase 10 mil para atingir uma marca superior a $45 \mathrm{mil}$ trabalhadores formais ligados diretamente ao canteiro de obras, chegando, no mesmo ano,

Gráfico 2 - Quantidade de vínculos e remuneração média das empresas do setor de construção de edifícios em Belém, para as faixas de 0 a 5 salários-mínimos

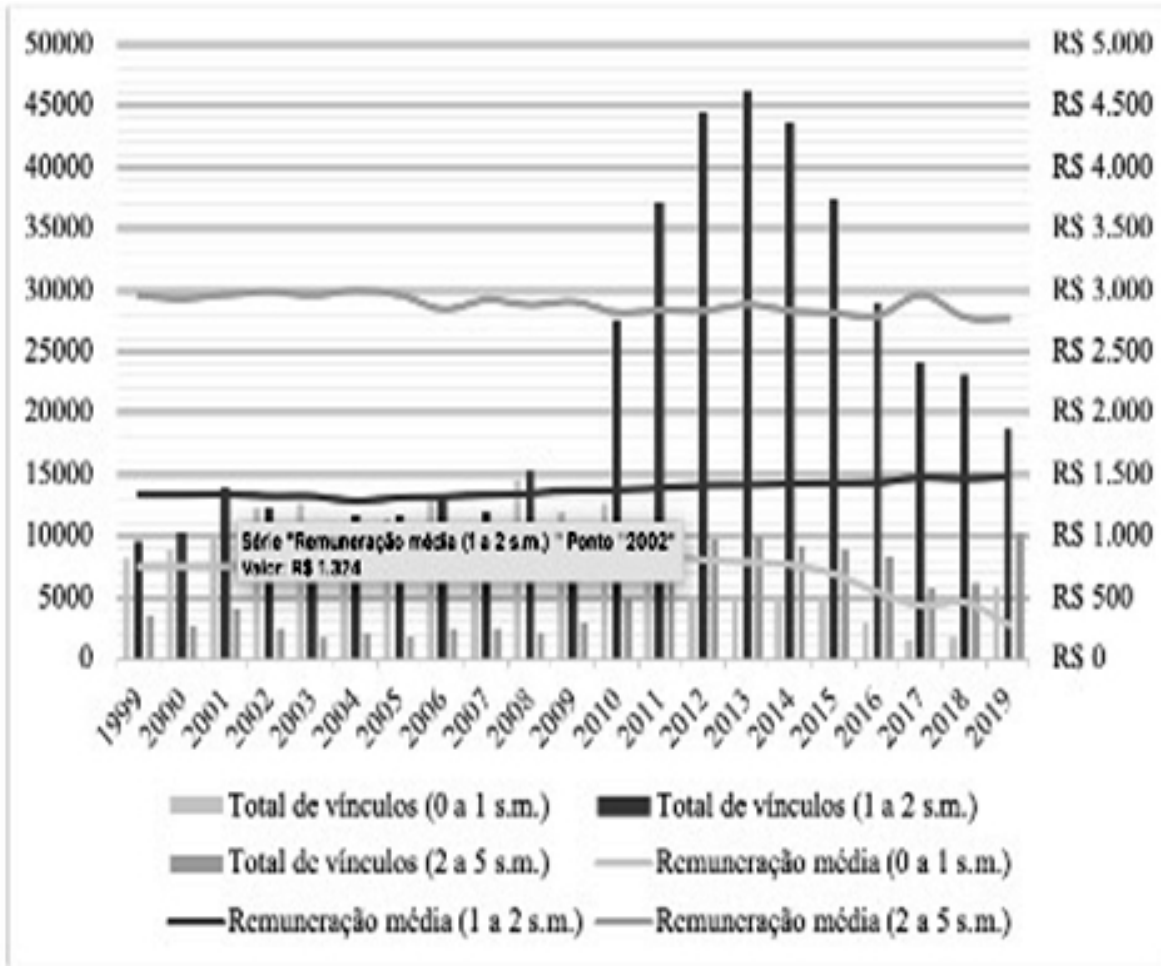

Fonte: Rais/ME. Elaboração Raul Ventura Neto. 
a mais de 61 mil vínculos, se acrescentarmos as outras faixas ao cálculo. 0 aumento no número de vínculos, no entanto, não é acompanhado do aumento da remuneração média do trabalhador do canteiro, observando-se, portanto, uma quase imobilidade na linha traçada a partir dos valores anuais de remuneração. Em duas décadas, o salário médio do trabalho do canteiro saiu de exatos $\mathrm{R} \$ 1.339,00$ para pouco mais de $R \$ 1.481,00$, para a faixa de 1 a 2 SM, caindo progressivamente na faixa de 0 a $1 \mathrm{SM}$, a partir de 2015. Em situação oposta à dos trabalhadores do canteiro (Gráfico 3), os dados de remuneração média nas faixas superiores a 10 SM apresentam, em média, uma remuneração de aproximadamente $R \$ 16.000,00$, atingindo patamares superiores a $\mathrm{R} \$ 22.000,00$ nos anos de 2011 e 2012, período de maior crescimento no número de entregas, conforme mostrou o Gráfico 1. Ademais, o período coincide com o aumento no número de empreendimentos do PMCMV, sobretudo em municípios da RMB, onde incorporadoras e construtoras, com sede em Belém, construíram, aproximadamente, 27 mil unidades habitacionais nas três faixas do programa, até o ano de 2013 (Lima et al., 2015).

Gráfico 3 - Quantidade de vínculos e remuneração média das empresas do setor de construção de edifícios em Belém, para as faixas de 5 salários-mínimos ou mais

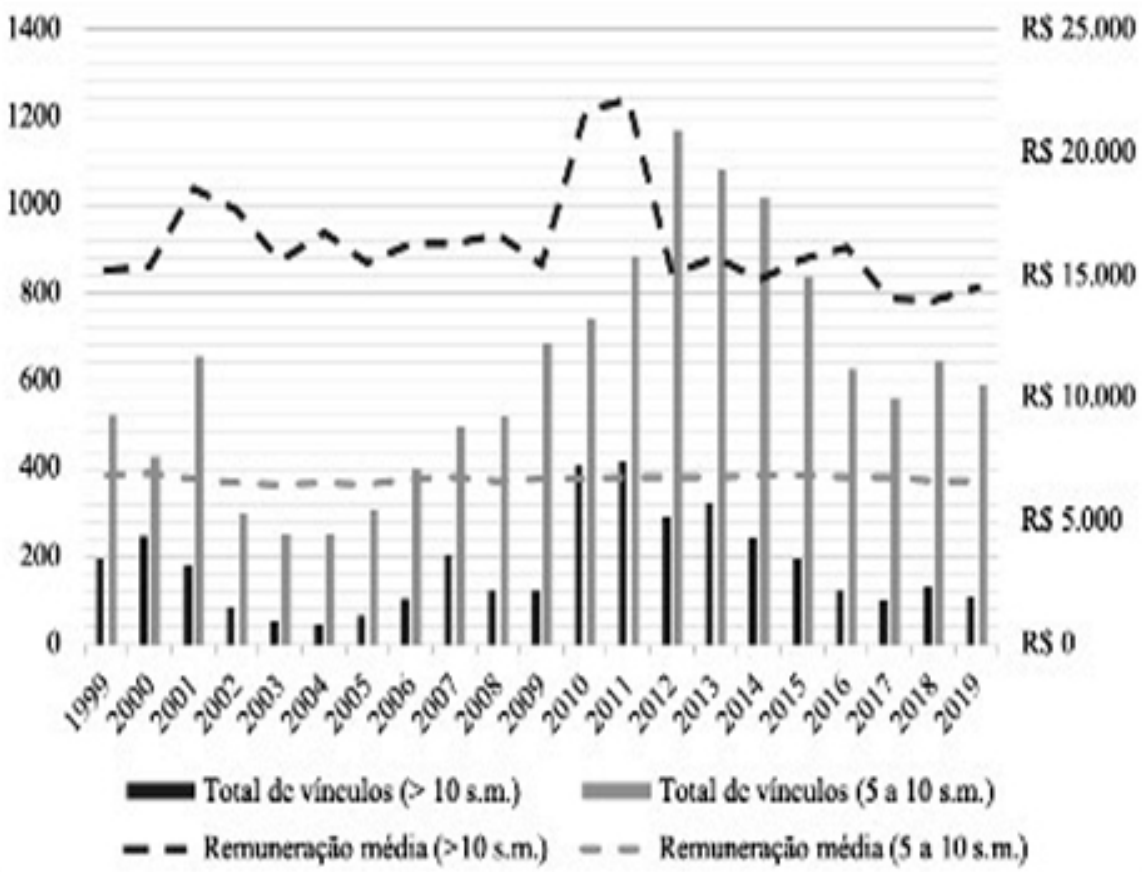

Fonte: Rais/ME. Elaboração Raul Ventura Neto. 
Os dados da Rais evidenciam como, durante o terceiro ciclo imobiliário em Belém, as empresas de construção de edifícios detinham capacidade de absorção de novos vínculos no canteiro de obras, sobretudo nas faixas inferiores, sem que isso levasse a um movimento de elevação na remuneração média. Pelo contrário, o aumento de produtividade parece ocorrer a despeito da elevação na composição orgânica do trabalho no canteiro, acontecendo por meio de novas formas de extração de níveis superiores de mais-valia absoluta, por inovações nas rotinas de trabalho que elevam a intensidade da jornada.

As incorporadoras de capital aberto encerram suas atividades no circuito imobiliário de Belém, bem como de outros circuitos imobiliários periféricos, conforme a crise econômica, que se aprofunda a partir de 2015, levou a uma queda nos indicadores dessas empresas na bolsa de valores, que passam a adotar como estratégia a venda dos ativos localizados nesses mercados para recuperar liquidez e confiança nos investidores (Penha Filho, 2020). Após a saída, é possível observar um processo de retomada dos lançamentos e finalização de obras que foram deixadas inacabadas por incorporadoras que entraram em processo de recuperação judicial durante a crise. Trata-se, nesse caso, dos empreendimentos da PDG S/A, incorporadora nacional que se associou a uma das maiores incorporadoras locais, a Construtora Leal Moreira, que ficou responsável pela finalização dos empreendimentos lançados para os segmentos médios e de alta renda. $\mathrm{Na}$ Figura 2 consta um infográfico que acumula a trajetória das maiores incorporadoras locais, ${ }^{21}$ identificando o momento de entrega do primeiro e do último empreendimento em cada um dos ciclos analisados neste artigo.

Figura 2 - Infográfico com a trajetória das incorporadoras locais ao longo dos ciclos

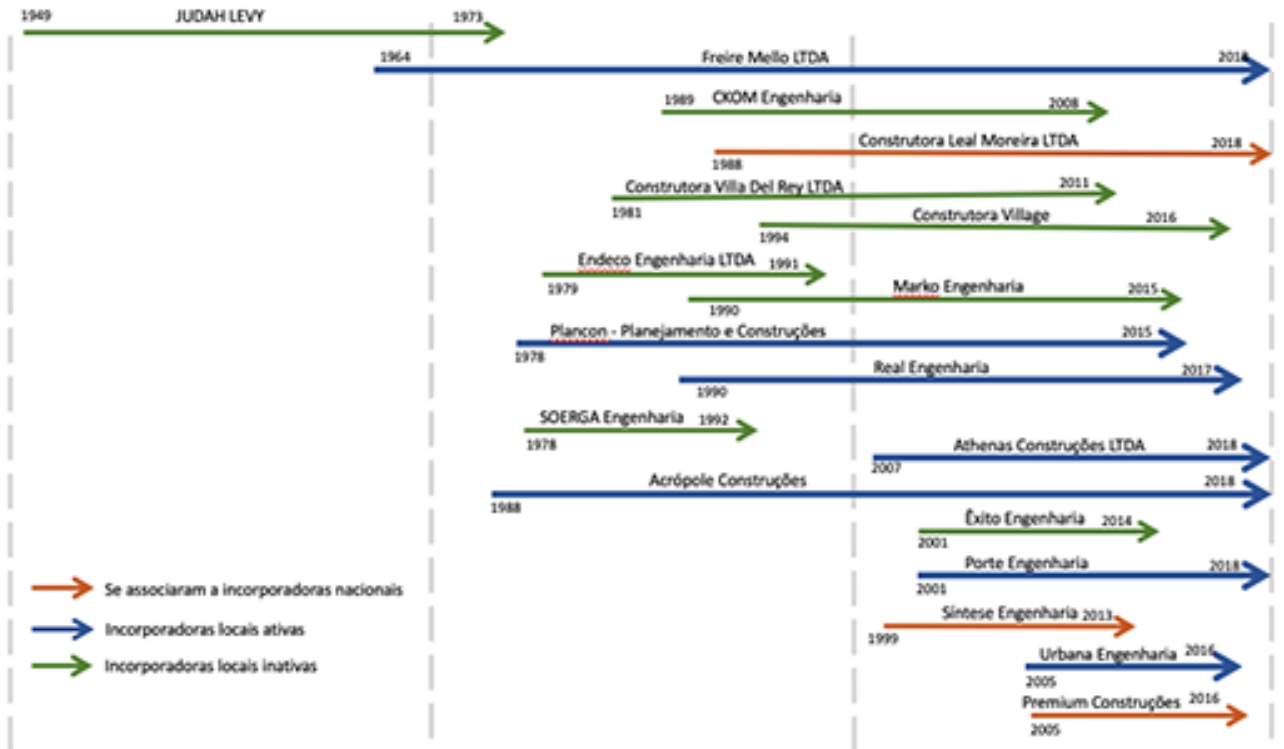

Fonte: IBGE, 2020; Seurb; Núcleo Belém do Observatório das Metrópoles. Elaboração: Raul Ventura Neto. 
Por fim, a saída das incorporadoras nacionais e mesmo a venda dos ativos que possuíam na cidade, incluindo o estoque de unidades, que foi vendido abaixo do preço de mercado, não levara, a mudanças substanciais na dinâmica do mercado de terras de Belém. Os preços dos imóveis, nas áreas de maior atuação do capital incorporador, mantiveram-se próximos ao patamar que atingiram nos anos de 2008 a 2009, no auge do terceiro ciclo, quando a busca por terrenos e o lançamento de novos empreendimentos levaram à forte elevação do preço da terra.

O Gráfico 4 mostra a evolução do preço por metro quadrado para a ZAU-6, área de maior atuação do capital incorporador desde o segundo ciclo, como mostra a Figura 1. É possível notar uma correspondência entre a evolução dos preços com o Gráfico 1, que mostra o ritmo de entrega dos empreendimentos. Conforme se lançavam e se entregavam mais unidades, maior passava a ser o preço do imóvel, o que nos remete à espiral de preços crescentes, semelhante ao que definiu Pereira (2018). É perceptível, no Gráfico 4, uma mudança de patamar de preços, a partir de 2009, em relação ao valor do metro quadrado dos apartamentos, que apresenta um crescimento na ordem de $211 \%$ em relação a 2006,22 mantendo-se no patamar médio superior a $\mathrm{R} \$ 4.000,00$ até $o$ ano de 2019. De modo similar, os preços dos terrenos apresentam uma forte expansão

Gráfico 4 - Evolução do preço por metro quadrado na ZAU-6 durante o terceiro ciclo

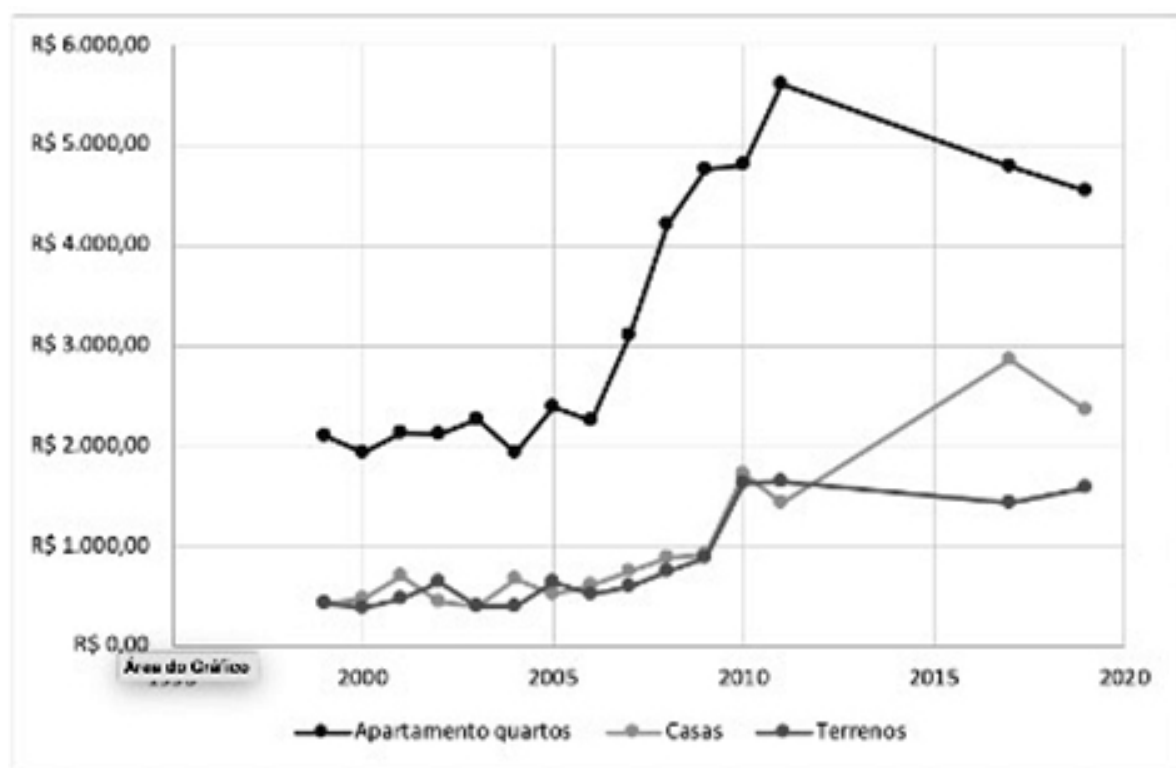

Fonte: classificados do jornal O Liberal. Elaboração Mariana Santos (Pibic). 
entre os anos de 2008 e 2010 saltando aproximadamente $R \$ 600,00$ em 2007, para um valor superior a $\mathrm{R} \$ 1.600,00$ no ano de 2010, provavelmente como resultado do acirramento na busca por terrenos para novos empreendimentos nas faixas 2 e 3 dos PMCMV.

\section{Considerações finais}

É sempre difícil a ideia de organizar, em períodos ou ciclos, processos tão complexos como os que descrevemos ao longo deste artigo. Buscou-se, com o trabalho, desnudar como as elites locais, proprietárias de imóveis e terra urbana, vêm organizando o circuito imobiliário local para os seus interesses imediatos de acumulação. Apesar de sintéticos, argumentamos que a leitura na forma de ciclos imobiliários seja fundamental para observar os elementos estruturais que definem a história dos espaços urbanos "criados" pela ação incorporadora do capital. Tal abordagem parece, nos tempos de hoje, elucidativa quanto à compreensão dos limites que enfrentamos para promover cidades menos desiguais e democráticas. Os ciclos imobiliários que aconteceram em Belém não deixaram a cidade mais rica e, muito possivelmente, tendem a comprometer a renda familiar dos que adquiriram imóveis durante o último ciclo por muito mais tempo, além de serem impulsionadores de um processo de concentração de renda, como os dados da Rais buscaram evidenciar.

Ao mesmo tempo, o novo patamar de preços da terra urbana tem mostrado um estímulo fundamental para o aumento de lançamentos imobiliários a partir de 2018, dando início ao que parece ser um processo de uma aparente reestruturação no circuito imobiliário de Belém. A retomada tem sido conduzida especialmente por novas incorporadoras e construtoras que, ou não estavam presentes no ciclo anterior, ou atuavam de forma bem restrita. A área central voltou a ser palco de empreendimentos de alto padrão, com forte predomínio da apropriação paisagística da orla da cidade. A "Nova Belém" segue como fronteira imobiliária de novos loteamentos para as camadas médias, em glebas de pequeno porte dispersas na região, que se tornam viáveis para loteamentos de alto padrão pelo valor do metro quadrado da região, mas também em glebas de grande porte que assumiram valores inimagináveis na década anterior. ${ }^{23}$ Além disso, com a reestruturação recente, observa-se a configuração de tendências de avanço da centralização entre incorporadoras locais, que, pela primeira vez, passaram a desvincular-se das atividades de construção e atuar unicamente na incorporação e venda do edifício. Entende-se que a elevação do preço da terra urbana foi a principal herança do ciclo imobiliário marcado pela atuação de incorporadoras de capital aberto. Como uma nuvem de gafanhoto, para usar uma metáfora do geógrafo Neil Smith, um tipo financeirizado de capital incorporador atuou, em associação com as incorporadoras locais, para extrair enormes parcelas de renda fundiária, que apareciam para o "público-alvo" como prestações mensais, anuais e as "chaves", que não passam de formas de condenar o trabalho futuro ao pagamento de juros.

Novas rodadas de lançamentos imobiliários e, possivelmente, um novo ciclo de atividades e incorporação irão iniciar em alguns anos nas metrópoles, provavelmente requentando os mesmos elementos estruturais 
identificados em ciclos anteriores: a abertura de novas frentes imobiliárias, as construções simbólicas para ressignificar espaços periféricos, o aumento da intensidade sobre a jornada de trabalho no canteiro e as mudanças de patamar sobre o preço da terra. Contudo, é preciso indagar por quanto tempo mais uma cidade de base econômica limitada, como Belém, consegue seguir como espaço para criação exacerbada de capital fictício. Pelo que parece, o interesse recente da World Trade Center Association, caso se confirme, pode indicar que tais limites ainda estejam longe de serem atingidos. A ver.

\section{[I] https://orcid.org/0000-0001-7124-1002}

Universidade Federal do Pará, Faculdade de Arquitetura e Urbanismo, Programa de Pós-Graduação em Arquitetura e Urbanismo, Programa de Pós-Graduação em Economia. Belém, PA/Brasil.

raulvneto@ufpa.br

\section{Notas}

(1) A literatura sobre os diversos instrumentos que o SFI mobiliza foi satisfatoriamente tratada em inúmeros trabalhos de pesquisa. Como referência, sugerimos a leitura de: Royer (2013), Botelho (2007), Sanfelici (2013), Shimbo (2010).

(2) Em que pese a não existência de instituições oficiais de coleta de preços de imóveis em Belém, como metodologia de pesquisa adotada realizou-se um extenso levantamento em preços de imóveis anunciados no caderno de classificados do principal jornal da cidade, O Liberal. A coleta de dados foi conduzida pela bolsista de iniciação científica, Mariana Santos, sob minha orientação, entre os anos de 2019 e 2020. O levantamento selecionou dois domingos dos meses de janeiro, junho, julho e dezembro, do período que vai de 1999 a 2011, e posteriormente para os anos de 2017 e 2019. Esse intervalo ocorreu devido à paralisação das atividades da biblioteca Arthur Viana, onde se encontravam armazenados os jornais impressos, devido à pandemia da Covid-19, o que nos levou a acessar apenas as edições que se encontravam no sítio virtual do jornal. O recorte territorial da coleta envolveu quatro bairros incluídos na Zona de Ambiente Urbano 6 (ZAU-6), do plano diretor do município de Belém. O total de unidades levantadas nos classificados foi de 2.356 imóveis, segmentados entre 1.057 apartamentos, 423 terrenos e 876 casas. O valor de apartamentos corresponde a uma amostragem de aproximadamente $15 \%$ do universo estimado de domicílios particulares permanentes do tipo apartamento existentes na ZAU 6, segundo o censo de 2010 do IBGE. Os preços coletados foram devidamente corrigidos de acordo com o índice de inflação corresponde a cada mês, de cada ano, até o ano de 2020, gerado na calculadora do cidadão do Banco Central do Brasil, utilizando o Índice IPCA (IBGE).

(3) Lessa (1980) utiliza o termo capital imobiliário para se referir ao agente da economia urbana identificado como incorporador imobiliário. Optamos por fazer uso do conceito de capital incorporador ou capital de incorporação em nossas análises, por entendermos ser mais adequado aos objetivos deste artigo. 
(4) Em nota de rodapé do texto "Reflexões sobre o papel do capital mercantil na questão urbana e regional do Brasil”, Cano (2011) cita o trabalho de Lessa (1980) como referência que utilizou para conceituar o capital imobiliário no Brasil.

(5) A autora realça, ainda, a literatura produzida nos anos 1990 sobre a relação entre o Estado e as incorporadoras e, observando a produção mais recente sobre o tema, destaca também os trabalhos que avançam em pesquisas sobre a articulação entre as incorporadoras e o Estado nas políticas públicas de habitação.

(6) Em Shimbo (2020), é citado, ainda, o trabalho de Salgado (1984) sobre a tipologia dos incorporadores em São Paulo nos anos de 1970, contudo não foi possível localizar o material original durante a elaboração do artigo.

(7) A Importadora de Ferragens S.A. é uma empresa fundada em 1931 e que incialmente se dedicava aos mais diversos tipos de importações de produtos manufaturados, especialmente materiais para construção civil e material automotivo. Em poucos anos, a Importadora de Ferragens consolidou-se como a principal importadora da região, abrindo a primeira filial fora do Pará, em 1945, na cidade do Rio de Janeiro, onde ficou até meados dos anos de 1980. A empresa existe até hoje e atualmente se dedica a administrar os imóveis em propriedade da empresa e da família.

(8) Os valores monetários do levantamento foram devidamente deflacionados com a inflação acumulada até dezembro de 1960, utilizando o índice IPC (Fipe).

(9) Vacarias são pequenas unidades agrícolas, comuns nas áreas de baixada da cidade até os anos de 1970, onde, além de hortifrutigranjeiros, eram criados pequenos rebanhos de gado de leite.

(10) Os dados do SFH são desagregados apenas em nível estadual, contudo os municípios da RMB representam aproximadamente $1 / 3$ da população do estado e mais da metade dos domicílios particulares permanentes, segundo dados do censo de 2010 do IBGE.

(11) Os dados apresentados no gráfico foram coletados no arquivo da Secretaria de Urbanismo de Belém (Seurb) em três momentos distintos. Em 2007, em pesquisa conduzida pelo núcleo Belém do Observatório das Metrópoles, na qual se coletaram informações dos empreendimentos aprovados pela Seurb de 1940 a 2007. Em 2012, para subsidiar as análises que apresentamos em Ventura Neto (2012) e, por fim, em 2018, para subsidiar novas pesquisas que coordenamos no âmbito do projeto "Transformações recentes na morfologia de Belém a partir da LCCU/99". Nos três momentos, foram coletadas informações sobre o ano de emissão do Habite-se dos empreendimentos, além de informações gerais sobre o número de unidades e sobre o número de pavimentos.

(12) As facilidades obtidas com as mudanças no texto original da LCCU/1999 envolveram, ainda, a permanência de condições que haviam sido propostas pelo poder municipal no texto original da lei, aparentemente como forma de atender às demandas das empresas de incorporação e construção. Destaca-se, nessas condições, a exclusão das áreas condominiais do cálculo de aproveitamento do terreno, o que contribuiu para um aumento substancial nas tipologias identificadas como condomínios clubes.

(13) O plano diretor de Belém previa, em seu artigo 124, a elaboração de uma nova lei de uso e ocupação do solo até o ano de 2010, quando o quadro de modelos da LCCU/1999 seria definitivamente substituído, contudo, a minuta e os estudos para uma nova lei de uso e ocupação do solo nunca foram sequer elaborados pela prefeitura municipal. 
(14) Esses relatórios se encontram disponíveis no website da Comissão de Valores Imobiliários (CVM) e constituem-se material público, podendo ser baixados a qualquer momento. No caso da Gafisa, foram analisados, principalmente, os Relatórios Anuais (IAN), mas também os Relatórios Trimestrais (ITR) dos anos de 2005 a 2011. O mesmo procedimento foi adotado para obter informações financeiras e imobiliárias das outras incorporadoras nacionais de capital aberto que atuam em Belém. Disponível em: <http://www.cvm.gov.br>. Acesso em: 10 jul 2012.

(15) Até final de 2007, tendo em vista que, no relatório daquele ano, a empresa aponta que $87 \%$ do seu landbank havia sido adquirido por permuta, número que cai para 72\% no relatório de 2008.

(16) No ano de 2011, no auge dos lançamentos dos empreendimentos associados à nova Belém, a rodovia Augusto Montenegro teve a classificação alterada pela prefeitura municipal, passando para avenida Augusto Montenegro.

(17) Nesta pesquisa em específico, os ramos utilizados seguiram o modelo proposto e definido por Araújo et al. (2018), e são: Incorporação e atividades imobiliárias próprias; Construção de edifícios; Obras de infraestruturas; e Serviços especializados para construção.

(18) Para esta pesquisa, foram selecionados os dados referentes às empresas incluídas na seção $F$, divisão 41 da Classificação Nacional de Atividades Econômicas (Cnae) do IBGE.

(19) Os valores apresentados em cada faixa foram deflacionados para dezembro de 2019, último mês da coleta de dados.

(20) Segundo a Matriz Insumo-Produto produzida para o setor, em 2015, pelo governo do Estado, para cada R\$1 milhão de aumento da demanda final da construção civil, seria gerado $R \$ 0,494$ milhão de salários e/ou lucros, sendo que 37,5\% desse valor seria decorrente do efeito direto desse investimento.

(21) Nesse recorte, foram selecionados as incorporadoras e/ou construtoras que possuíam mais de 5 empreendimentos realizados.

(22) Esse valor confirma as estimativas declaradas por incorporadores locais que entrevistamos ainda entre os anos de 2011 e 2012.

(23) As últimas grandes glebas ainda disponíveis no eixo da avenida Augusto Montenegro (150 x $110 \mathrm{~m}$ ) têm sido oferecidas, em sites de venda de imóveis, no valor de $\mathrm{R} \$ 75$ milhões de reais, próximo a 4 mil reais o metro quadrado, valor atualmente praticado em empreendimentos à venda na região da "Nova Belém". 


\section{Referências}

ANITELLI, F.; TRAMONTANO, M. (2016). Edifícios de apartamentos, a peça: muda o cenário, mudam os atores, mas o roteiro permanece. Cadernos do Proarq, n. 27, pp. 75-88.

ARAÚJO, J. B. de; LIVRAMENTO, M. do; FINATTI, R.; MAROTA, R. (2018). Economias metropolitanas e desenvolvimento regional: uma proposta de classificação das atividades econômicas. In: CONGRESSO OBSERVATÓRIO DAS METRÓPOLES 20 ANOS. Anais... Rio de Janeiro, Observatório das Metrópoles.

BALL, M. (1983). Housing policy and economic power: the political economy of owner occupation. Londres/Nova York, Routledge.

BARAVELLI, J. E. (2017). Trabalho e tecnologia no programa MCMV. São Paulo, Annablume.

BOTELHO, A. (2007). O urbano em fragmentos: a produção do espaço e da moradia pelas práticas do setor imobiliário. São Paulo, Annablume/Fapesp.

BRANDÃO, C. A.; OLIVEIRA, F. L. P. D.; GUIMARÃES, L.; SANTOS, V. M. D. (2020). Wilson Cano, intérprete da questão regional e urbana no Brasil. Revista Brasileira de Estudos Urbanos e Regionais, v. 22, pp. 1-24.

CANO, W. (2011). Ensaios sobre a crise urbana do Brasil. Campinas, Editora Unicamp.

CARDOSO, A. C. D.; VENTURA NETO, R. D. S. (2013). A evolução urbana de Belém: trajetória de ambiguidades e conflitos socioambientais. Cadernos Metrópole, v. 15, n. 29, pp. 55-75.

CHAVES, T. A. P. V. (2011). Isto não é para nós? Um estudo sobre a verticalização e modernidade em Belém entre as décadas de 1940 e 1950. Dissertação de mestrado. Belém, Universidade Federal do Pará.

FIX, M. A. B. (2011). Financeirização e transformações recentes no circuito imobiliário no Brasil. Tese de doutorado. Campinas, Universidade Estadual de Campinas

IDESP - Instituto de Desenvolvimento Econômico, Social e Ambiental do Pará (1990). Avaliação das intervenções do poder público na questão habitacional no Pará Belém.

LENCIONI, S. (2014). Reestruturação imobiliária: uma análise dos processos de concentração e centralização do capital no setor imobiliário. Eure. Santiago, v. 40, n. 120, pp. 29-47.

LESSA, C. (1980). A crise urbana e o circuito imobiliário. [S.I.], Equipe P.E.H, c. (mimeo).

LESSA, C.; DAIN, S. (1982). “Capitalismo Associado: algumas referências para o tema Estado e Desenvolvimento”. In: BELLUZO, L.; COUTINHO, R. (orgs.). Desenvolvimento capitalista no Brasil: ensaios sobre a crise. São Paulo, Brasiliense.

LIMA, J. J. F. et al. (2015). “Estratégias de produção habitacional de interesse social através do PMCMC na Região Metropolitana de Belém e no sudeste do Pará”. In: SANTO AMORE, C.; SHIMBO, L. Z.; RUFINO, M. B. C. (orgs.) Minha Casa... E a cidade? Avaliação do Programa Minha Casa Minha Vida em seis estados brasileiros. Rio de Janeiro, Letra Capital.

MARICATO, E. (2009). Por um novo enfoque teórico na pesquisa sobre habitação. Cadernos Metrópole. São Paulo, v. 11, n. 21, pp. 33-52.

PENHA FILHO, C. A. (2020). Estratégias e dinâmicas de acumulação das incorporadoras listadas (20102018). Tese de doutorado. Campinas, Universidade Estadual de Campinas. 
PEREIRA, P. C. X. (1988). Espaço, técnica e construção: o desenvolvimento das técnicas construtivas e a urbanização do morar em São Paulo. São Paulo, Nobel.

(2018). "Para uma discussão sobre o valor e preço na produção imobiliária". In: PEREIRA, P. C. X. (org.). Imediato, global e total na produção do espaço: a financeirização da cidade de São Paulo no século XXI. Brasília, Ipea.

PINHEIRO, A. C. L.; PONTE, J. P. X.; VALENTE, A. M.; LIMA, A. L.; PINHEIRO, P. Q. F. (2016). “Assentamentos precários na Região Metropolitana de Belém: baixadas e ocupações”. In: MORAIS, M. P.; KRAUSE, C.; LIMA NETO, V. C. Caracterização e tipologia de assentamentos precários: estudos de caso brasileiros. Brasília, Ipea.

PONTE, J. X. (2010). A cidade e água no Estuário Guajarino. Tese de doutorado. Rio de Janeiro, Universidade Federal do Rio de Janeiro.

RANGEL, I. (2004). Questão agrária, industrialização e crise urbana no Brasil. Porto Alegre, Editora da UFRGS.

RIBEIRO, L. C. Q. (1997). Dos cortiços aos condomínios fechados: as formas de produção da moradia no Rio de Janeiro. Rio de Janeiro, Civilização Brasileira.

ROLNIK, K. (2015). Guerra dos lugares. A colonização da terra e da moradia na era das finanças. São Paulo, Boitempo.

ROYER, L. O. (2013). Financeirização da política habitacional: limites e perspectivas. São Paulo, Annablume.

(2016). O FGTS e o mercado de títulos de base imobiliária: relações e tendências. Cadernos Metrópole. São Paulo, v. 18, n. 35, pp. 33-52.

RUFINO, M. B. C. (2012). Incorporação da Metrópole: centralização do capital no imobiliário e nova produção do espaço em Fortaleza. Tese de doutorado. São Paulo, Universidade de São Paulo.

SANFELICI, D. (2013). A metrópole sob o ritmo das finanças: implicações socioespaciais da expansão imobiliária no Brasil. Tese de doutorado. São Paulo, Universidade de São Paulo.

(2016). Centralização do capital no setor imobiliário e reconfiguração das metrópoles. Mercator. Fortaleza, n. 15, pp. 7-21.

SANTANA, J. M. M. de; LIMA, J. J. F.; VENTURA NETO, R. da S. (2021). Mudanças em projetos arquitetônicos e a financeirização do capital em Belém, PA. PARC Pesquisa em Arquitetura e Construção. Campinas/SP, v. 12, n. 00, p. e021019. DOI: 10.20396/parc.v12i00.8660768. Disponível em: https://periodicos.sbu.unicamp.br/ojs/index.php/parc/article/view/8660768. Acesso em: 29 jul 2021.

SANTOS, T. V. (2011). Políticas públicas, planejamento e gestão urbanos no ambiente metropolitano: estudos sobre a Região Metropolitana de Belém. ACTA Geográfica, v. 5, n. 10, pp. 55-73.

SHIMBO, L. Z. (2010). Habitação social, habitação de mercado. A confluência entre Estado, empresas construtoras e capital financeiro. Tese de doutorado. São Carlos, Universidade de São Paulo.

(2016). Sobre os capitais que produzem habitação no Brasil. Novos estudos Cebrap, n. 35, pp. 119-133.

(2020). O concreto do capital: os promotores do valor imobiliário nas cidades brasileiras. Tese de livre-docência. São Carlos, Universidade de São Paulo. 
TAVARES, M. C. (1999). "Império, território e dinheiro". In: FIORI, J. L. (org.). Estados e moedas no desenvolvimento das nações. Petrópolis, Vozes.

TOPALOV, C. (1979). "Análise do ciclo de reprodução do capital investido na produção da indústria da construção civil: capital e propriedade fundiária". In: FORTI, R. (org.). Marxismo e urbanismo capitalista: textos críticos. São Paulo, Ciências Humanas.

TRINDADE JR., S.-C. C. (1997). Produção do espaço e uso do solo urbano em Belém. Belém, Naea/Ufpa. (1998). A cidade dispersa: os novos espaços de assentamento em Belém e a reestruturação metropolitana. Tese de doutorado. São Paulo, Universidade de São Paulo.

(2019). "Confinamento, dispersão e difusão: processos e configurações espaciais de uma metrópole em formação". In: TRINDADE JUNIOR, S.-C. C.; SANTOS, T. V. (orgs.). $O$ urbano e metropolitano em Belém: (re)configurações socioespaciais e estratégias de planejamento e gestão. Rio de Janeiro, Consequência.

VENTURA NETO, R. S. (2015). Belém e o imobiliário: uma cidade entre contratos e contradições. Belém, Ioepa.

(2017). (Trans) Formação socioespacial da Amazônia: floresta, rentismo e periferia. Tese de doutorado. Campinas, Universidade Estadual de Campinas.

VENTURA NETO, R. da S.; MOURA, B. M. (2019). Jardins de granito: impactos da verticalização sobre as áreas permeáveis da primeira légua patrimonial de Belém. Revista Projetar - Projeto e Percepção do Ambiente, v. 4, n. 3, pp. 38-53.

VENTURA NETO, R. S.; LIMA, J. J. (2019). "Financeirização truncada e reestruturação metropolitana: a dimensão espacial do capital financeiro imobiliário na Região Metropolitana de Belém". In: TRINDADE JUNIOR, S.-C. C.; SANTOS, T. V. (orgs.). O urbano e metropolitano em Belém: (Re)configurações socioespaciais e estratégias de planejamento e gestão. Rio de Janeiro, Consequência.

VENTURA NETO, R. S.; BARROS, N. S.; PONTE, J. P. X.; SANTOS, R. B. N. dos (2020) "Dinâmica econômica da Região Metropolitana de Belém (2006-2016): impactos do socialdesenvolvimentismo e efeitos da inflexão liberal recente". In: RIBEIRO, M.; CLEMENTINO, M. L. M. Economia metropolitana e desenvolvimento regional: do experimento desenvolvimentista à inflexão. Rio de Janeiro, Letra Capital.

Texto recebido em 31/mar/2021

Texto aprovado em 17/jun/2021 